Article

\title{
Estimation of $\mathrm{CO}_{2}$ Emissions from Wildfires Using OCO-2 Data
}

\author{
Meng Guo ${ }^{1}{ }^{1}$, Jing $\mathrm{Li}^{2, *}$, Lixiang Wen ${ }^{1}$ and Shubo Huang ${ }^{1}$ \\ 1 Key Laboratory of Geographical Processes and Ecological Security in Changbai Mountains, Ministry of \\ Education, School of Geographical Sciences, Northeast Normal University, Changchun 130024, China; \\ guom521@nenu.edu.cn (M.G.); wenlx679@nenu.edu.cn (L.W.); huangsb966@nenu.edu.cn (S.H.) \\ 2 Northeast Institute of Geography and Agricultural Ecology, Chinese Academy of Science, \\ Changchun 130102, China \\ * Correspondence: lijingsara@iga.ac.cn
}

Received: 15 August 2019; Accepted: 24 September 2019; Published: 25 September 2019

\begin{abstract}
The biomass burning model (BBM) has been the most widely used method for estimation of trace gas emissions. Due to the difficulty and variability in obtaining various necessary parameters of $\mathrm{BBM}$, a new method is needed to quickly and accurately calculate the trace gas emissions from wildfires. Here, we used satellite data from the Orbiting Carbon Observatory-2 (OCO-2) to calculate $\mathrm{CO}_{2}$ emissions from wildfires (the OCO-2 model). Four active wildfires in Siberia were selected in which OCO-2 points intersecting with smoke plumes identified by Aqua MODIS (MODerate-resolution Imaging Spectroradiometer) images. MODIS band 8, band 21 and MISR (Multi-angle Imaging SpectroRadiometer) data were used to identify the smoke plume area, burned area and smoke plume height, respectively. By contrast with $\mathrm{BBM}$, which calculates $\mathrm{CO}_{2}$ emissions based on the bottom-top mode, the OCO-2 model estimates $\mathrm{CO}_{2}$ emissions based on the top-bottom mode. We used a linear regression model to compute $\mathrm{CO}_{2}$ concentration $\left(\mathrm{XCO}_{2}\right)$ for each smoke plume pixel and then calculated $\mathrm{CO}_{2}$ emissions for each wildfire point. The $\mathrm{CO}_{2}$ mass of each smoke plume pixel was added to obtain the $\mathrm{CO}_{2}$ emissions from wildfires. After verifying our results with the BBM, we found that the biases were between $25.76 \%$ and $157.11 \%$ for the four active fires. The OCO-2 model displays the advantages of remote-sensing technology and is a useful tool for fire-emission monitoring, although we note some of its disadvantages. This study proposed a new perspective to estimate $\mathrm{CO}_{2}$ emissions from wildfire and effectively expands the applied range of OCO-2 satellite data.
\end{abstract}

Keywords: wildfire; $\mathrm{CO}_{2}$ emission; OCO-2; MISR; MINX

\section{Introduction}

Land carbon storage is strongly influenced by ecosystem disturbances, which influence species composition and structure and cause a net carbon stock reduction [1]. Wildfires are one of the most significant disturbances to land ecosystems on regional and global scales and generate large amounts of critical greenhouse gases (GHG), especially $\mathrm{CO}_{2}$. Wildfires play a key role in global biogeochemical cycles, atmospheric composition, and land ecosystem attributes, all of which influence

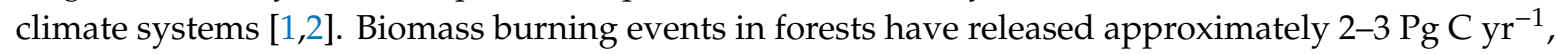
mostly in the form of $\mathrm{CO}_{2}$ [2-5]. With increasing temperatures due to global warming and the accompanying drying trends, wildfires have increased in boreal forests over the last few decades [6].

Boreal forests are the most important global terrestrial carbon stocks, and $\mathrm{CO}_{2}$ released into the atmosphere by wildfires may convert forests from carbon sinks into net sources, which in turn contributes to global warming and affects the carbon cycle [7]. Wildfires also impact the climate through changes in the surface albedo [8]. Siberia's boreal forests cover more than $60 \%$ of the total 
global area [7]. The ability to accurately estimate $\mathrm{CO}_{2}$ emissions from boreal forest fires is necessary to understand the role of Siberia in the global carbon cycle.

Seiler and Crutzen [9] were the first to propose a biomass burning model (BBM) to calculate $\mathrm{CO}_{2}$ released from biomass burning. Following that, many researchers have estimated $\mathrm{CO}_{2}$ emissions from wildfires in different regions using the BBM. Miranda, et al. [10] forecasted $\mathrm{CO}_{2}$ emissions from forest fires in Portugal between 1988 and 2010 and argued that $\mathrm{CO}_{2}$ emissions increased from $28 \mathrm{Tg}$ in 1988 to $44 \mathrm{Tg}$ in 2010. Wiedinmyer and Neff [11] calculated $\mathrm{CO}_{2}$ emissions from fires in the US and found $\sim 80 \mathrm{Tg}$ of $\mathrm{CO}_{2} \mathrm{yr}^{-1}$ were emitted in Alaska from 2002 to 2006. With the help of remote-sensing imagery, burned area data were retrieved and combined with results from previous research on burning efficiency and emission factors, showing that annual forest fire $\mathrm{CO}_{2}$ emissions from 23 European countries were 8.4-20.4 Tg [12]. Werf, et al. [13] estimated the fire emissions from 1997 to 2009 with 0.5-degree spatial resolution and monthly temporal resolution using a revised biogeochemical model and found that the average global fire carbon emission was $2.0 \mathrm{Pg} \mathrm{C}^{-1}$ and the contribution from forest fires was $15 \%$. Rosa, et al. [14] studied changes in burned areas and found that $\mathrm{CO}_{2}$ emission from biomass burning in Portugal was 159-5655 Gg from 1990 to 2008. Shi and Yamaguchi [15] developed a new high-resolution biomass burning emission inventory during 2001-2010 in Southeast Asia based on satellite products and combustion factors and found an average of $817.81 \mathrm{Tg}$ of $\mathrm{CO}_{2}$ emissions every year. Zhou, et al. [16] calculated the biomass burning emissions in mainland China in 2012 using satellite data and source-specific emission factors and found that $675.30 \mathrm{Tg}$ of $\mathrm{CO}_{2}$ was emitted.

As we know, many parameters are needed in BBM, such as above-ground fuel load, combustion efficiency, and emission factors. However, all of these parameters are not easy to obtain, need field surveys and laboratory tests, and require a large amount of cost for labor and resources. With the development of remote sensing, a new method is needed to improve the efficiency of wildfire emissions.

In recent years, the relationships between of fire radiative power (FRP) with biomass consumed and emission factors have been successfully used to estimate trace gases released into the atmosphere [17-22]. Konovalov, et al. [21] estimated $\mathrm{CO}_{2}$ emissions from wildfires in Siberia in 2012 using the direct relationship between biomass burning rate (BBR) and FRP and obtained the result of 262-477 Tg $\mathrm{C}$, but the accuracy requires further analysis. Today, many biomass burning emission inventories exist, such as the Global Fire Emissions Database (GFED) [23], Fire INventory from National Center for Atmospheric Research (NCAR) (FINN) [24], and Global Fire Assimilation System (GFAS) [25]. All these data sets have made great contributions to wildfire emission research, but all these products are based on the BBM or FRP. Further, these products constitute global emissions at coarse spatial resolution on monthly or daily temporal scales. No product is available that is focused on biomass burning emissions of active fires or in times of fire occurrence.

Due to the ability of remote-sensing technology to obtain data and repeat sampling in large forested regions, active burning can be identified in inaccessible locations or where using aircraft observation is too costly [26]. It could even be predicted that in the near future, greenhouse gas-monitoring satellites such as GOSAT (Greenhouse Gases Observing Satellite), OCO-2 (Orbiting Carbon Observatory-2), and TanSat (CarbonSat) will play a key role in tracking biomass burning emissions, which will help us better understand the contributions of biomass burning to regional climate change and atmospheric composition $[7,27,28]$. By using OCO-2 data, Heymann, et al. [27] estimated that $\mathrm{CO}_{2}$ emissions from Indonesian wildfires in 2015 were $30 \%$ lower than provided by the emission databases of GFAS version 1.2 and GFED version 4s. In their paper, they used OCO-2 $\mathrm{XCO}_{2}$ (column-averaged dry air mole fraction of $\mathrm{CO}_{2}$ ) as the main data source and derived the difference between the fire-affected $\mathrm{XCO}_{2}$ values and background $\mathrm{XCO}_{2}$ values. Proposing a new method and a new perspective to estimate $\mathrm{CO}_{2}$ emissions from wildfires. Patra, et al. [28] also used OCO-2 and atmospheric chemistry-transport model to estimate the $C$ release during the 2014 2016 El Niño and found that $2.4 \pm 0.2 \mathrm{Pg} C$ was released into the atmosphere.

In our previous work, Guo, et al. [7], we demonstrated for the first time the ability of GOSAT data to estimate $\mathrm{CO}_{2}$ emissions from forest fires. Given the limitations of GOSAT data in estimating 
$\mathrm{CO}_{2}$ emissions such as sparse observed points of TANSO-FTS (Thermal And Near-infrared Sensor for carbon Observation-Fourier Transform Spectrometer) and a narrow swath of CAI (Cloud and Aerosol Imager) observations mentioned in Guo, et al. [7], this paper attempts to use another GHG satellite, OCO-2, combined with MODIS (MODerate-resolution Imaging Spectroradiometer) and MISR (Multi-angle Imaging SpectroRadiometer) data to estimate $\mathrm{CO}_{2}$ emissions from wildfires.

\section{Materials and Methods}

\subsection{Orbiting Carbon Observatory-2 (OCO-2) Data}

OCO-2, launched on 2 July 2014, is a National Aeronautics and Space Administration (NASA) mission to study $\mathrm{CO}_{2}$ in the atmosphere to better understand the carbon cycle and to track and quantify $\mathrm{CO}_{2}$ sources and sinks on a global scale [29] as well as their impact on climate. OCO-2 is a polar sun-synchronous orbit satellite with a return cycle of 16 days and crosses the equator at 13:35 LT (local time). OCO-2 estimates the column-averaged dry air mole fraction of $\mathrm{CO}_{2}$ (denoted as $\mathrm{XCO}_{2}$, in ppm) from Earth's surface to the top of the atmosphere. When radiances pass through the atmosphere, $\mathrm{CO}_{2}$ and $\mathrm{O}_{2}$ will absorb radiance at specific wavelengths. $\mathrm{XCO}_{2}$ is calculated by using the ratio of column $\mathrm{CO}_{2}$ densities and $\mathrm{O}_{2}$ molecules along the optical path between the Sun, ground surface, and OCO-2 sensor and is then multiplied with the column-averaged $\mathrm{O}_{2}$ concentration [30-32]. OCO-2 carries a three-band imaging instrument that measures the $\mathrm{O}_{2} \mathrm{~A}$-band at $0.76 \mu \mathrm{m}$ and two $\mathrm{CO}_{2}$ bands at 1.61 and $2.06 \mu \mathrm{m}$ to measure the weak and strong $\mathrm{CO}_{2}$ bands, respectively [33-36].

OCO-2 is an excellent remote-sensing satellite for the study of atmospheric $\mathrm{CO}_{2}$ which collects global atmospheric $\mathrm{CO}_{2}$ with high precision and resolution $[27,37,38]$. The OCO-2 instrument covers a $1.29 \times 2.25 \mathrm{~km}$ footprint at nadir and is capable of acquiring eight cross-track footprints, creating a swath width of 10.3 kilometers, to obtain $\mathrm{XCO}_{2}$ values. Near-simultaneous measurements of $\mathrm{XCO}_{2}$ using ground-based the Fourier Transform Spectrometers in Total Carbon Column Observing Network (TCCON) were used to validate the accuracy of $\mathrm{XCO}_{2}$ products from OCO-2 and found that after bias correction, the $\mathrm{XCO}_{2}$ extracted from OCO-2 agreed well on a global scale with the TCCON for nadir, glint, and target observations, with median differences less than $0.5 \mathrm{ppm}$ and root-mean-square differences obviously below $1.5 \mathrm{ppm}[27,30]$. Many researchers found that net variable errors of OCO-2 $\mathrm{XCO}_{2}$ were $\sim 0.5$ to $2.0 \mathrm{ppm}$ over land $[29,31]$.

As we know, OCO-2 only collects data in clear skies because the presence of aerosol, such as clouds, may increase the uncertainty of the $\mathrm{XCO}_{2}$ value [39]. However, in this study, the bias was ignored as we selected the OCO-2 points which intersected light smoke plumes. We assumed that the bias compared with the clear sky condition was the result of forest fire $\mathrm{CO}_{2}$ release $[7,40,41]$.

OCO-2 L2 Lite FP V8r data with NetCDF format (downloaded from the websites https://mirador. gsfc.nasa.gov/) which contain daily data of retrieved values for the state vector and geolocation information were used in this study.

\subsection{Smoke Plumes and Burned Area Monitor Using Moderate-Resolution Imaging Spectroradiometer (MODIS) Data}

MODIS is a key instrument aboard the Terra (across the equator in the morning) and Aqua (across the equator in the afternoon) satellites. Terra MODIS and Aqua MODIS sample the entirety of the Earth's surface with a 2330-km swath, providing near-global daily coverage. MODIS acquires data in 36 spectral bands from 0.4 to $14.4 \mu \mathrm{m}$ at three spatial resolutions: $250 \mathrm{~m}$ (band 1 and 2), $500 \mathrm{~m}$ (band 3-7), and 1000-m (band 8-36) covering visible, near-infrared, shortwave infrared (IR), and thermal-IR regions in the electro-magnetic spectrum [42]. Bands 1 to 7 are specifically designed for remote sensing of land [43].

Comparing MODIS false-color images with each single band, we found that MODIS band 8 $(4.05-4.2 \mu \mathrm{m})$ could identify smoke plumes clearly and has higher correlation with $\mathrm{XCO}_{2}$ values in the intersected points. In this study, we used MODIS band 8 to identify smoke plumes. 
The launch of MODIS effectively improved the capabilities in fire detection compared with other sensors given active fire detection bands that allow for the retrieval of sub-pixel temperatures at 3.9 and $11 \mu \mathrm{m}$ which have been successfully used for detecting fire locations [42,44,45]. Both actively burning fires and post-fire burned areas can be identified using MODIS data. Middle-infrared-to-thermal wavelengths $(3.6-12 \mu \mathrm{m})$ were mainly used to detect actively burning fires based on the combustion temperature. The post-fire burned area was mainly extracted visually to a near-infrared band $(0.4-1.3 \mu \mathrm{m})$ by way of the reduction of surface reflectance when vegetation is removed [46]. MODIS band $21(3.929-3.989 \mu \mathrm{m})$ has been widely used in forest fire and volcano research [47,48], and in this study, we used it to monitor burned areas. Active fires and the recently burned scars all have higher temperatures which can be captured by MODIS band 21.

The orbit of Aqua MODIS is sun-synchronous, near-polar, and crosses the equator at 1:30 p.m. MODIS data and products have been successfully used in many fields, including land cover changes, environmental monitoring, global warming, landscape ecology, etc. In this paper, Aqua MODIS L1b data were used to map the burned scars and to detect smoke plumes.

\subsection{Multi-Angle Imaging Spectroradiometer (MISR) Data and MISR Interactive Explorer (MINX) Software}

MISR is part of NASA's first Earth Observing System spacecraft, the Terra spacecraft, which was launched on 18 December 1999. Unlike other satellite instruments, MISR records images of the Earth at 9 different angles in each of 4 color bands simultaneously. MISR's 36 simultaneous spectral-angular images have been widely used in aerosol optical depth, cloud, and smoke plumes study [4,49-51].

The MISR INteractive eXplorer (MINX) software is used to retrieve and analyze the heights and winds locally of smoke, dust, and clouds at higher spatial resolution and with greater precision [50,52]. MINX is specially designed to display images from MISR's nine cameras and to determine the height and speed of motion of aerosol plumes and clouds on those images. This software has been the best-established tool in smoke plume height estimation and using this tool, thousands of plume heights have been derived in MISR Plume Height Project (https://misr.jpl.nasa.gov/getData/accessData/ MisrMinxPlumes2/). MINX can use MODIS thermal anomalies to locate active fires, and then computes the smoke plume heights from MISR stereo imagery [51,52]. It is a robust tool in analyzing the physical properties of smoke plumes and plume dynamics. In this study, MINX V4.0 was used to identify smoke plumes and derive the height [52-54].

\subsection{Wildfire Cases Selected in Boreal Forest}

We targeted wildfires covered by Aqua MODIS images and OCO-2 on the same day where OCO-2 points must intersect wildfire smoke plumes. The MODIS products of MCD64A1 and Landsat images were used to obtain wildfire information. Then, we downloaded the Aqua MODIS L1B images covering the wildfires and identified smoke plumes visually. Based on the time span of wildfires and spatial range of smoke plumes, OCO-2 L2 data covering smoke plumes were downloaded to look for the intersect points. We selected one wildfire that met our standard in Siberia (on 20 April 2015), the cross time was 20 April 2015 05:13:08 and 20 April 2015 05:15:00 LT for OCO-2 and Aqua MODIS, respectively (Figure 1). 


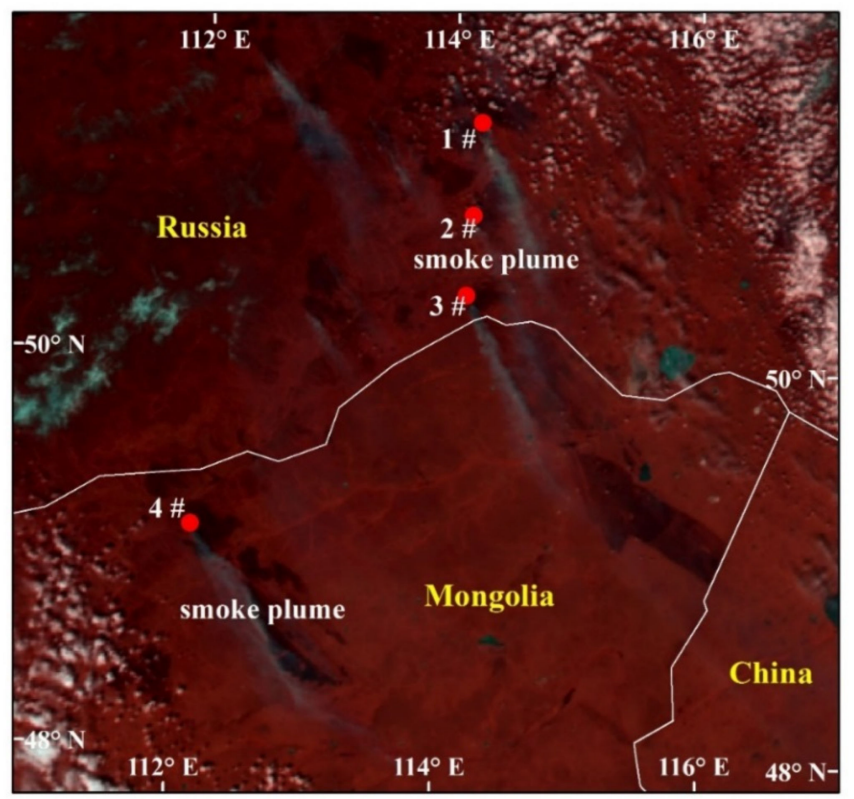

Figure 1. Moderate-resolution Imaging Spectroradiometer (MODIS) false-color image (red-green-blue $(\mathrm{RGB})=741)$ of study region. The white lines indicate national boundaries and the red point is fire point. Smoke plumes can be identified from the image. We found 3 active fires in Russia and 1 in Mongolia, but here, the study region is labeled "Siberia".

\section{5. $\mathrm{CO}_{2}$ Emission Method (OCO-2 Model)}

In this study, we are going to explore a new method to quantify the $\mathrm{CO}_{2}$ released from wildfires that is based on the transitional equation of mass calculation as shown below:

$$
\mathrm{E}_{\mathrm{CO} 2}=\rho \times \mathrm{V}
$$

$\mathrm{E}_{\mathrm{CO} 2}$ indicates $\mathrm{CO}_{2}$ emissions from wildfire, $\rho$ is the density of $\mathrm{CO}_{2}$, and $V$ is the volume of smoke plumes calculated using $S$ (area) and multiplied by $H$ (height). $S$ is the area of smoke plumes calculated from MODIS images and $H$ is the height of smoke plumes, which will be derived using MINX. The equation can thus be expressed as follows:

$$
\mathrm{E}_{\mathrm{CO} 2}=\rho \times \mathrm{S} \times \mathrm{H}
$$

As shown before, the unit of OCO-2 $\mathrm{XCO}_{2}$ data is parts per million (ppm). To calculate the quantity of $\mathrm{CO}_{2}$ released from wildfires, it was necessary to convert these numbers to density values using

$$
\rho=\mathrm{M} / 22.4 \times \mathrm{ppm} \times(273 / \mathrm{T}) \times(\mathrm{Ba} / 1013.25)
$$

where $\rho\left(\mathrm{mg} / \mathrm{m}^{3}\right)$ is the density of $\mathrm{CO}_{2}$ in the atmosphere, $M$ is the molecular weight of $\mathrm{CO}_{2}, 22.4$ indicates the molecular mass of atmosphere, ppm is the value of $\mathrm{XCO}_{2}, T$ is the temperature $(\mathrm{K})$, and $\mathrm{Ba}$ is the atmospheric pressure (hPa) [7]. $\mathrm{XCO}_{2}$ values are determined by dry air, but $M$ and 22.4 values are within standard atmospheric pressure. In this research, we ignore the uncertainty of water vapor concentration in the atmosphere and the smoke was uniformly distributed from the ground surface to the top of smoke plumes. We also assume that all smoke that released from forest fires was captured by MODIS without being dispersed into the atmosphere. To calculate the $\mathrm{CO}_{2}$ emissions from wildfires, we must know $\triangle \mathrm{XCO}_{2}$, which is the difference between $\mathrm{XCO}_{2}$ in smoke plume regions and the background value of $\mathrm{XCO}_{2}$. Base $\mathrm{XCO}_{2}$ is represented as the mean value of OCO-2 points surrounding the smoke plumes ( 10 km around) and the value is $399.786 \mathrm{ppm}$. 
The temperature and atmospheric pressure are referenced from the L137 model-level definitions (https://www.ecmwf.int/en/forecasts/documentation-and-support/137-model-levels).

\subsection{Biomass Burning Model (BBM)}

BBM $[9,41]$ has been widely used to evaluate trace gas emission from wildfires and for studying the release of trace gases from biomass burning [55-57]. It is calculated based on the conservation of mass:

$$
\mathrm{Es}=\mathrm{S} \times \mathrm{B} \times \beta \times \mathrm{EF}
$$

where $\mathrm{Es}(\mathrm{Mg})$ is $\mathrm{CO}_{2}$ emissions from wildfires, $S$ is the burned area (ha) as indicated from satellite images, $B$ is the biomass fuel load $\left(\mathrm{Mg} \mathrm{ha}^{-1}\right), \beta$ is the combustion factor $(\%)$, and $E F$ is the emission factor of $\mathrm{CO}_{2}\left(\mathrm{~kg} \mathrm{~kg}^{-1}\right)$.

Many researchers used different approaches to obtain the BBM parameter for different ecological systems $[13,56,58]$. Among them, Akagi, et al. [59] summarized much of the literature data for biomass consumption for different vegetation and fire types, and in this paper we used the parameter of Akagi, et al. [59] to calculate $\mathrm{CO}_{2}$ emissions which were used to verify the accuracy of OCO-2 model.

\section{Results}

\subsection{Smoke Plume Area Detection and Height Derivation}

To calculate $\mathrm{CO}_{2}$ emissions from wildfires, we must know smoke plume characteristics such as height, distribution, and the value of $\mathrm{XCO}_{2}$. First, smoke plumes from wildfire must be detected accurately. Remote-sensing data can accomplish this work quite well and MODIS data were suitable for this study. Using the threshold of MODIS band 8, we detected the smoke plumes of the 4 fire cases (Figure 2) with area of $2.48 \times 10^{3} \mathrm{~km}^{2}, 2.41 \times 10^{3} \mathrm{~km}^{2}, 2.50 \times 10^{3} \mathrm{~km}^{2}$ and $6.48 \times 10^{3} \mathrm{~km}^{2}$, respectively.
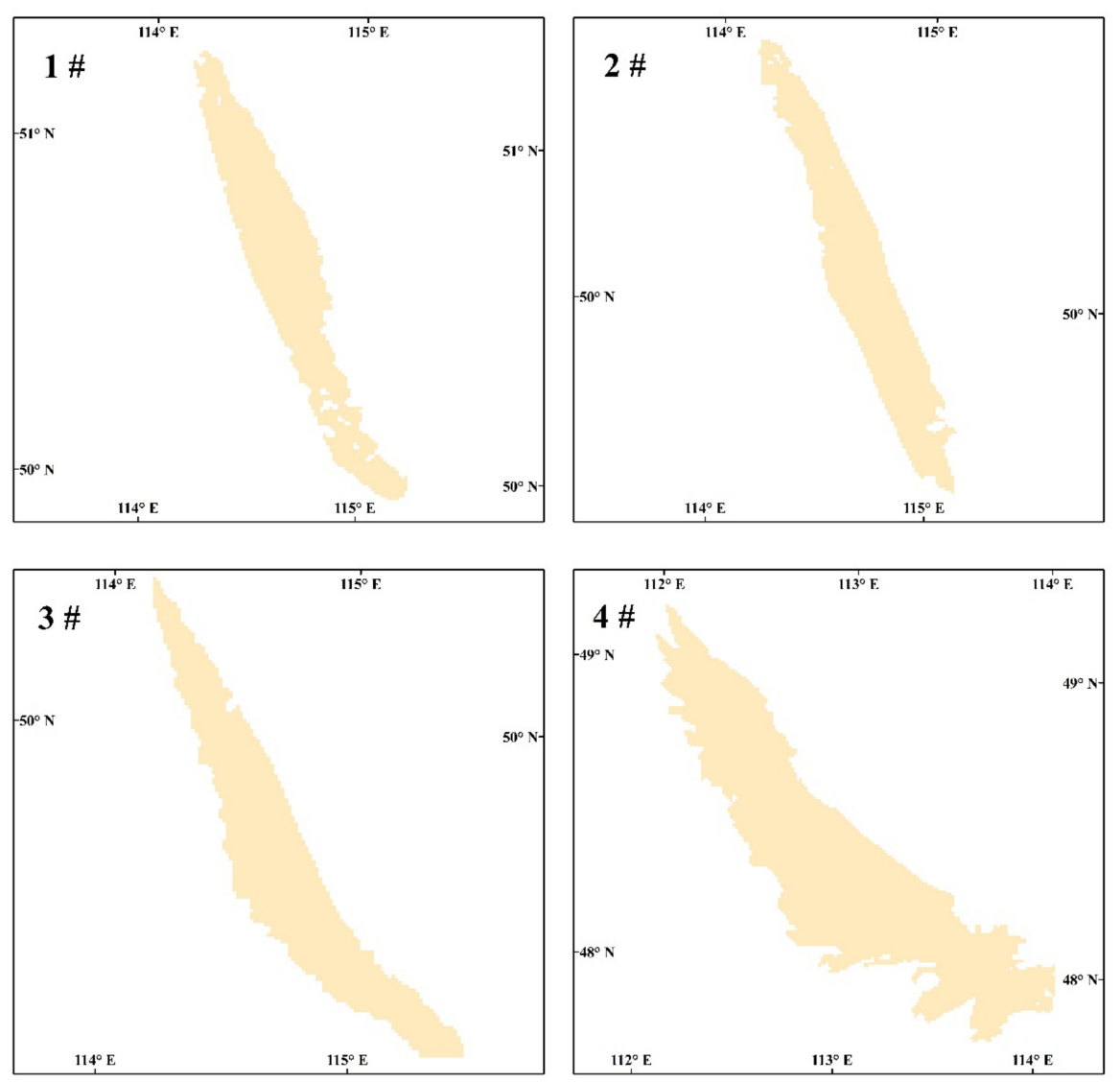

Figure 2. Smoke plumes detection using MODIS band 8 . 
As mentioned above, MINX has the potential to extract smoke characteristics and here we combine MINX and MODIS data to identify smoke plumes. By employing MINX v4.0, we derived the height of each wildfire smoke plume (Figure 3). We calculated the average height of each smoke plume pixel and obtained the height value as $2.29 \mathrm{~km}, 2.38 \mathrm{~km}, 1.99 \mathrm{~km}$, and $2.61 \mathrm{~km}$ for the 4 smoke plumes, respectively.
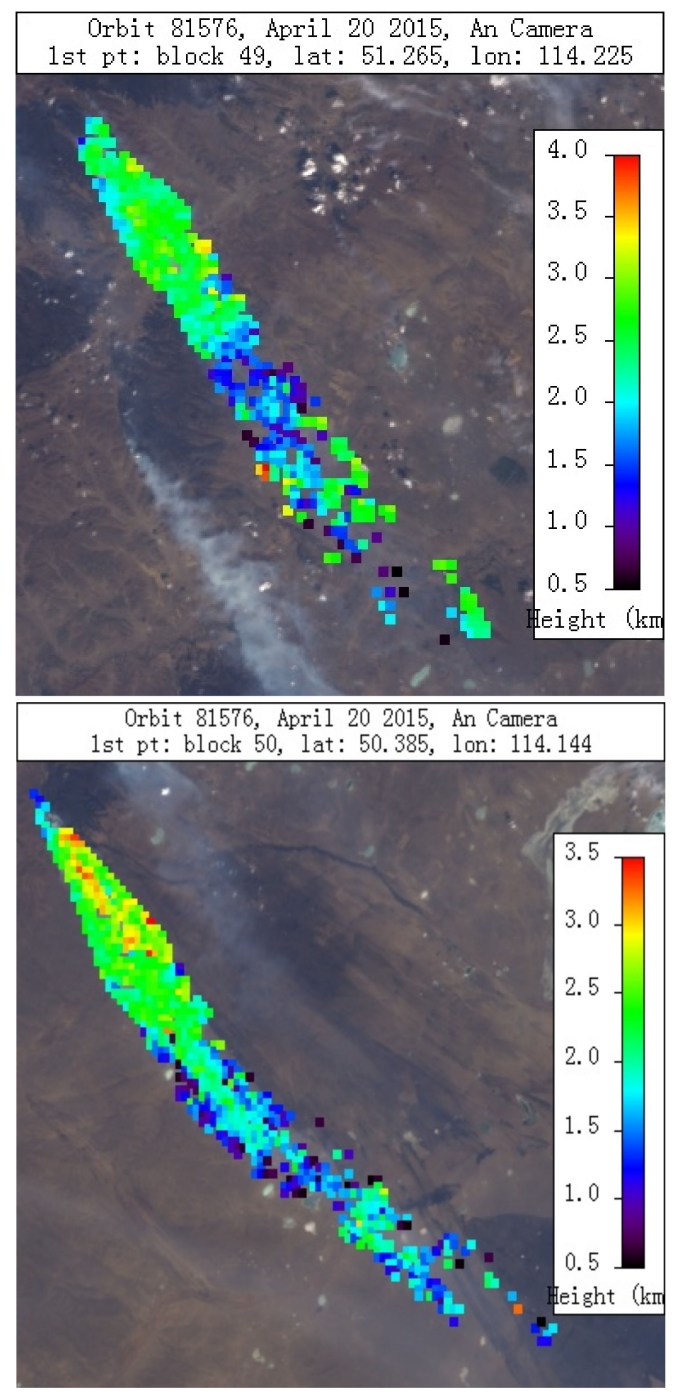

Figure 3. Height of smoke plume sketches derived from Multi-Angle Imaging Spectroradiometer (MISR) data by employing MISR Interactive Explorer (MINX) v4.0 software.

From MINX results we can also obtain the smoke plume area of $1.46 \times 10^{3} \mathrm{~km}^{2}, 1.31 \times 10^{3} \mathrm{~km}^{2}$, $1.36 \times 10^{3} \mathrm{~km}^{2}$, and $1.04 \times 10^{3} \mathrm{~km}^{2}$, respectively which are rather lower than that from MODIS band 8 . MINX was robust in deriving aerosol height but could only recognize thick smoke which could be easily identified from true color images. MODIS band 8 has the potential to derive thin smokes using the reflectance threshold.

\subsection{Burned Area Monitor}

Burned area of forest fires could be accurately and rapidly monitored using remote-sensing images based on sharp differences in the spectral characteristics of the surface inside and outside of the burned scars. Using MODIS band 21 (MYD021KM.A2015110.0515.006.2015110190452) fire points were observed and visual interpretation was used to map the burned scars (Figure 4). Here, we assume that 
the smoke plumes were released from the mapped burned scars. Given that the spatial resolution of MODIS is $1000 \mathrm{~m}$, the burned scars must contain many mixed pixels. This means that the burned areas used in this study are worth discussion.

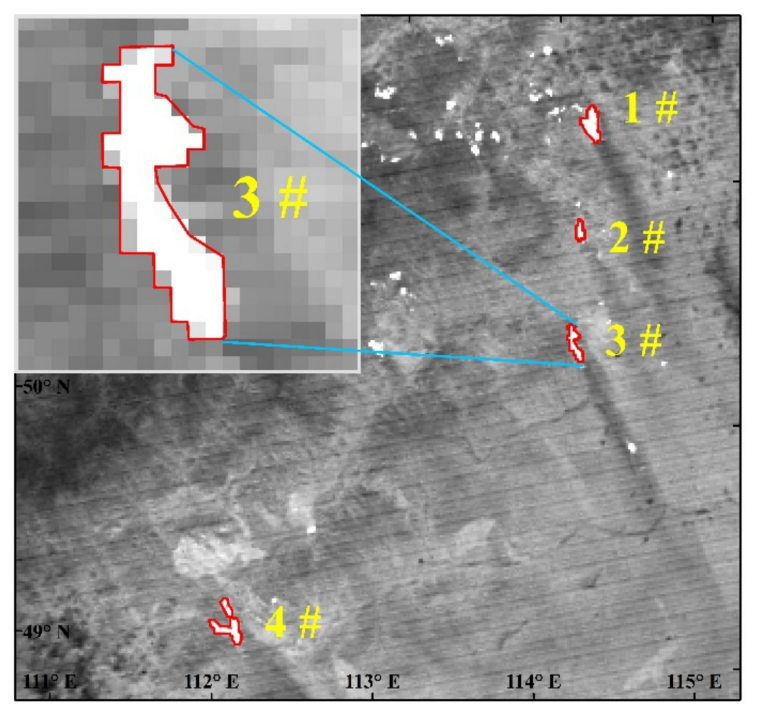

Figure 4. Burned area from MODIS band 21, and the upper-left corner is the enlarged images of the $3 \#$ fire scar.

\subsection{Model $\mathrm{XCO}_{2}$ from Smoke Plumes}

The $\mathrm{XCO}_{2}$ values of smoke plume pixels changed with the smoke concentration. To calculate $\mathrm{CO}_{2}$ emissions accurately, we first calculated $\mathrm{XCO}_{2}$ values for each smoke plume pixel and then subtracted clear sky $\mathrm{XCO}_{2}$ values. In this paper, linear regression analysis was used based on OCO-2 $\mathrm{XCO}_{2}$ values and MODIS band 8 reflectance in the intersection regions. Scatter plots of $\mathrm{XCO}_{2}$ against MODIS band 8 reflectance in the study region are shown in Figure 4 and close correlations were found $\left(R^{2}=0.655\right.$, $p<0.001$ ). By using the relationships between MODIS band 8 reflectance and $\mathrm{XCO}_{2}$, we could calculate $\mathrm{XCO}_{2}$ of the smoke plume pixels that did not intersect with OCO-2 points (Figure 5). In Figure 6 we see that $\mathrm{XCO}_{2}$ also has different values because of differences in smoke concentration. Higher values are in the center, and lower values are at the edges of the smoke plumes. $\mathrm{XCO}_{2}$ values decreased with increasing transport distance.

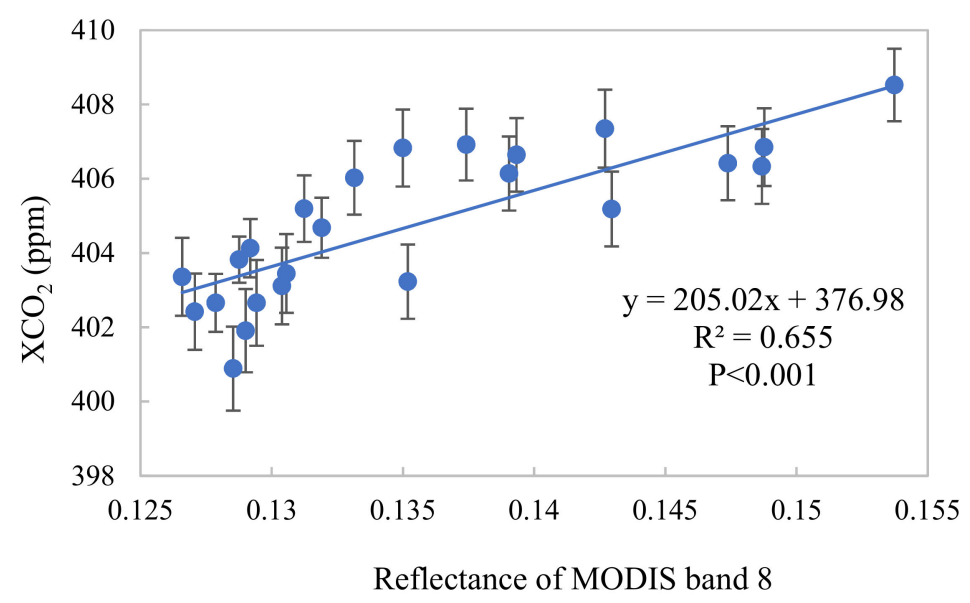

Figure 5. Scatter plots of reflectance of MODIS band 8 vs. Orbiting Carbon Observatory-2 (OCO-2) $\mathrm{CO}_{2}$ concentration in the study region. 

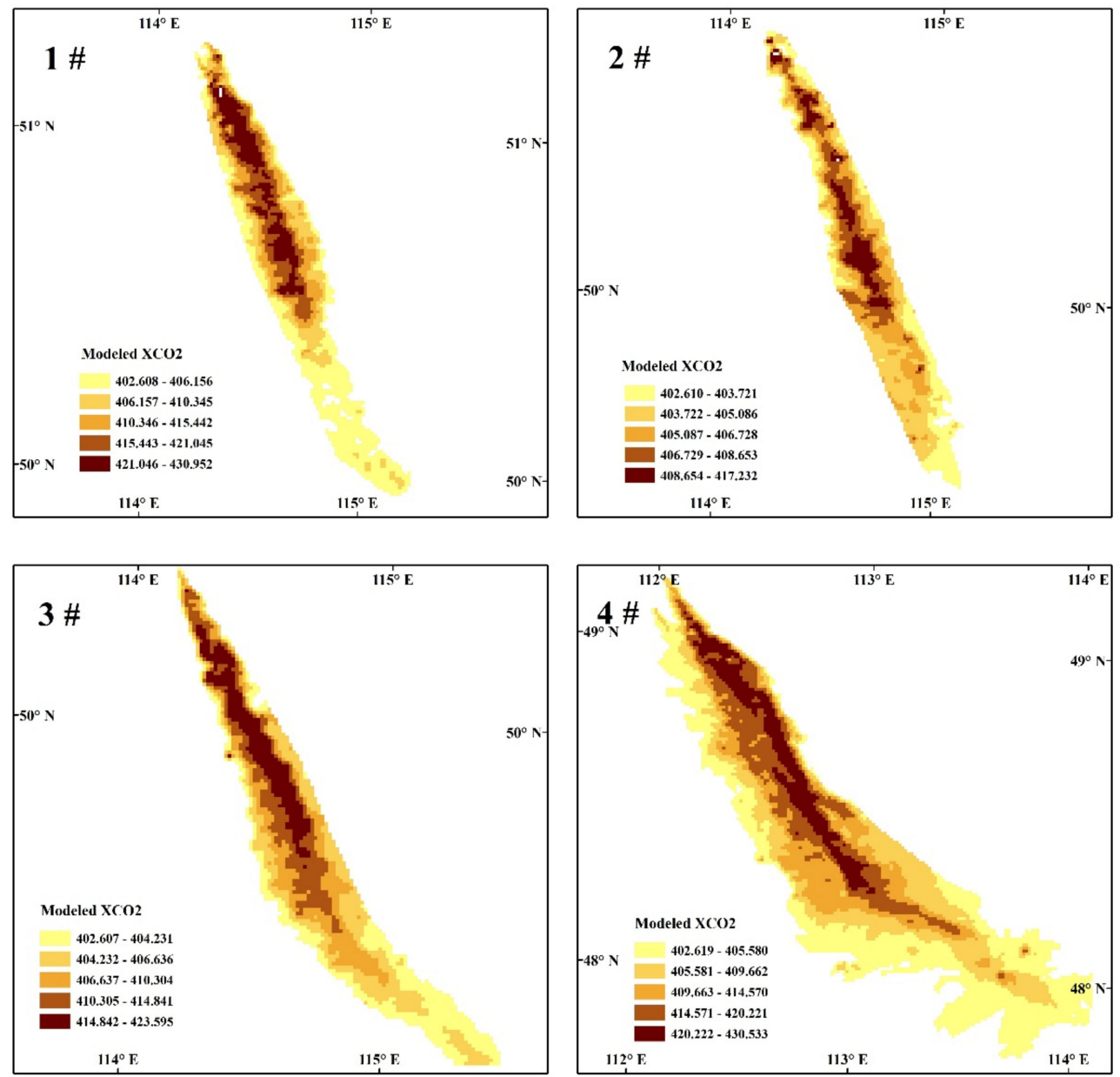

Figure 6. XCO2 values of smoke plumes calculated from MODIS band 8 reflectance.

\section{4. $\mathrm{CO}_{2}$ Emission Calculation from OCO-2 Model}

Equations 1-3 (named the OCO-2 model) were used to calculate $\mathrm{CO}_{2}$ emissions from wildfires. In the OCO-2 model, the height of the smoke plumes was derived from MISR data using MINX v4.0 software, the smoke plumes were derived from MODIS band 8. The calculated $\mathrm{CO}_{2}$ emissions for each fire point are shown in Table 1. We found that $\mathrm{CO}_{2}$ emissions were from $122.21( \pm 4.87) \times 10^{3} \mathrm{Mg}$ for the $2 \#$ wildfire to $288.70( \pm 14.33) \times 10^{3} \mathrm{Mg}$ for the 4 \# wildfire.

Table 1. $\mathrm{CO}_{2}$ emission values and calculated parameters for each fire point by OCO-2.

\begin{tabular}{ccccccc}
\hline $\begin{array}{c}\text { Fire Point } \\
\text { No. }\end{array}$ & $\begin{array}{c}\text { Smoke Plume Area } \\
\left(\mathbf{( 1 0}^{\mathbf{3}} \mathbf{~ k m}^{\mathbf{2}}\right)\end{array}$ & $\begin{array}{c}\text { Smoke Plume } \\
\text { Height } \mathbf{( k m )}\end{array}$ & $\begin{array}{c}\text { Base } \mathbf{X C O}_{\mathbf{2}} \\
(\mathbf{p p m})\end{array}$ & $\mathbf{T} \mathbf{( K )}$ & $\mathbf{B a} \mathbf{( h P a )}$ & $\begin{array}{c}\mathbf{C O}_{\mathbf{2}} \text { Emission } \\
\left.\mathbf{( 1 0 ^ { 3 }} \mathbf{~ M g}\right)\end{array}$ \\
\hline $1 \#$ & 2.48 & 2.29 & & & & $156.25( \pm 4.85)$ \\
$2 \#$ & 2.41 & 2.38 & 399.786 & 281.59 & 906.97 & $122.21( \pm 4.87)$ \\
$3 \#$ & 2.50 & 1.99 & & & $122.84( \pm 4.21)$ \\
$4 \#$ & 6.48 & 2.61 & & & $288.70( \pm 14.33)$ \\
\hline
\end{tabular}

\section{Discussion}

\subsection{Smoke Plume Height Estimation}

Energy from wildfires, especially crown fire, can loft smoke plumes above the boundary layer and promote long-distance transport of gases and particulate matter. Not all smoke aerosols rise high enough and form plumes. A great number of smoke aerosols remain in the near-ground layer $[4,49]$. 
From OCO-2 model we know that the height of smoke plume is rather important in determining the accuracy of $\mathrm{CO}_{2}$ emissions. Regarding the height of smoke plumes, researchers acquire different results using different methods for different fires. Vadrevu, et al. [60] used Cloud-Aerosol Lidar and Infrared Pathfinder Satellite Observations (CALIPSO) to monitor the mean smoke height and suggested that the value was from 2.5 to $9.3 \mathrm{~km}$ with an average height of $5.35 \mathrm{~km}$ at the northern border of India. Using multi-wavelength lidar, MODIS, and CALIOP imageries, $\mathrm{Wu}$, et al. [61] obtained different elevation values of smoke plumes from 1.5 to $6.5 \mathrm{~km}$ for different fire case locations. Ross, et al. [41] assumed the plume height was $0.3,1,2$, and $5 \mathrm{~km}$ to assess the ratio of $\mathrm{XCO}_{2}$ and $\mathrm{XCH}_{4}$ from GOSAT in the presence of wildfire plumes. Guo, et al. [7] used GOSAT FTS-TIR L2 data to identify the boundary of smoke plumes in a Russian wildfire of 2010 and obtained the height of $1.58 \mathrm{~km}$; however, this result warrants discussion because of the coarse resolution of GOSAT profile data. Kahn, et al. [50] calculated the height of smoke plumes in Australia using the Multi-angle Imaging SpectroRadiometer (MISR) instrument and found wind-corrected values of approximately $3.5 \mathrm{~km}$. Mazzoni, et al. [49] employed MISR and MODIS data collected over North America during the summer of 2004 and found that the plume height was approximately $3 \mathrm{~km}$ (see Figure 5 in Mazzoni, et al. [49]).

By employing MINX v4.0, we calculated the height of each wildfire smoke plume as shown in Figure 3. To simplify, we calculated the average height of each smoke plume pixel and obtained the height value as $2.29 \mathrm{~km}, 2.38 \mathrm{~km}, 1.99 \mathrm{~km}$, and $2.61 \mathrm{~km}$ respectively for the 4 smoke plumes. Compared with former research, we found that our results were slightly lower for the average smoke plume height which is mainly due to lower energy released from small burned areas.

\section{2. $\mathrm{CO}_{2}$ Emissions by $\mathrm{BBM}$}

Using OCO-2 model, we have estimated $\mathrm{CO}_{2}$ releases from 4 fire scars in Siberia. As we have shown, this is the first time that there has been a determination of $\mathrm{CO}_{2}$ emissions from forest fires using OCO-2 data. We employed BBM, the most commonly used method in estimating trace gases emission from biomass burning $[11,13,21]$, to verify the accuracy of our results.

As mentioned above, it is difficult and complex to obtain these variables accurately because of the high spatial heterogeneity of vegetation, different weather conditions, and different behaviors of each fire $[7,14]$. It is also quite difficult for us to field measure all these variables in Siberia by ourselves. Luckily, each variable, such as biomass fuel load, combustion factor, and $E F$, have been discussed by many researchers in recent years. Based on the former researchers' results, Werf, et al. [13] argued that the $E F$ in an extratropical forest was $1572 \mathrm{~g} \mathrm{~kg}^{-1}$. Based on localized measurements, Zhou, et al. [16] found that the EF was $1543-1630 \mathrm{~g} \mathrm{~kg}^{-1}$ in Chinese forests. The study by Shi and Yamaguchi [15] found an $E F$ of $1580 \mathrm{~g} \mathrm{~kg}^{-1}$ in the forests of Southeast Asia. Chang and Song [56] used an EF value of $1618 \mathrm{~g} \mathrm{~kg}^{-1}$ for the forest to estimate biomass burning emissions in tropical Asia. Akagi, et al. [59] used emission ratios (the molar ratio between the two emitted compounds) to derive $E F$ based on the carbon mass balance method. Laboratory- and ground-based measurements and airborne measurements of $E F$ for burning organic soils, peat, and woody/down/dead vegetation by many researchers were considered in order to calculate $E F$ by Akagi, et al. [59], who concluded that the $E F$ of $\mathrm{CO}_{2}$ for boreal forests is $1.489( \pm 0.121) \mathrm{kg} \mathrm{kg}^{-1}$. The study region in this work is located at high latitudes where the most important boreal forests in the world exist which is similar with Akagi et al.'s research. Thus, in this paper, we used the EF of $1.489( \pm 0.121) \mathrm{kg} \mathrm{kg}^{-1}$.

Akagi, et al. [59] summarized much of the literature data for biomass consumption (biomass loading multiply combustion factor) for different vegetation and fire types and we used their result of $38 \mathrm{Mg} \mathrm{ha}^{-1}$ here.

$\mathrm{CO}_{2}$ emissions from each fire scar and all other variables are shown in Table 2. The comparisons with the results of the OCO-2 model are also listed. We found that the results by the BBM are higher than those of the OCO-2 model for all 4 fire scars. The most similar results were found in the second fire scar $(25.76 \%)$; the largest bias was in the first fire scar $(157.11 \%)$ followed by the third $(121.10 \%)$. We found that all of the study cases have an equal magnitude of $\mathrm{CO}_{2}$ emission results by the $\mathrm{BBM}$ and 
OCO-2 models. Thus, we can propose that OCO-2 has great potential in estimating $\mathrm{CO}_{2}$ emissions from wildfires.

Table 2. $\mathrm{CO}_{2}$ emission values and calculated parameters for each fire scar using the BBM.

\begin{tabular}{|c|c|c|c|c|c|}
\hline $\begin{array}{c}\text { Fire Point } \\
\text { No. }\end{array}$ & $\begin{array}{l}\text { Burned Area } \\
\text { (ha) }\end{array}$ & $\begin{array}{c}B \times \beta \\
(\mathrm{Mg} / \mathrm{ha})\end{array}$ & EF (kg/kg) & $\begin{array}{c}\mathrm{CO}_{2} \text { Emission } \\
\left(10^{3} \mathrm{Mg}\right)\end{array}$ & $\begin{array}{l}\text { Compared with } \\
\text { OCO-2 Model }\end{array}$ \\
\hline $1 \#$ & 7100 & \multirow{4}{*}{38} & \multirow{4}{*}{$1.489(0.121)$} & $401.73( \pm 32.65)$ & $+157.11 \%$ \\
\hline $2 \#$ & 2700 & & & $153.69( \pm 12.41)$ & $+25.76 \%$ \\
\hline $3 \#$ & 4800 & & & $271.59( \pm 22.07)$ & $+121.10 \%$ \\
\hline $4 \#$ & 7500 & & & $424.37( \pm 34.49)$ & $+46.99 \%$ \\
\hline
\end{tabular}

\section{3. $\mathrm{CO}_{2}$ Emission Differences between the Two Models}

Table 2 show the different $\mathrm{CO}_{2}$ releases from boreal forest fires between BBM and OCO-2 models. We found that the BBM results are higher than those of the OCO-2 (from $25.76 \%$ to $157.11 \%$ ) but remain within our expected range.

The differences may be due to the uncertainty variables of BBM. The biomass fuel load and combustion factors are crucial but difficult to estimate accurately. Biomass fuel load estimates are complex because of the high spatial heterogeneity of the different types of vegetation sampled. Biomass fuel load (here, we just consider the aboveground biomass) was calculated at three levels: litter, surface fuels, and tree crowns; all these three levels change with species and vegetation type and are also affected by the age structure of the forest, the years since the last disturbance, and so on $[14,41]$. Saatchi, et al. [62] found that the error of forest biomass fuel load is about $50 \%$. The boreal forest is made up by many different biological communities with different biomass loads. The burned scars, especially the larger ones, usually contain many biological communities. The study region is located at the edge of Siberia and the vegetation communities may differ with former research. In this paper, we did not consider biological communities and used one value for the study region. Biomass fuel load based on vegetation community information may increase the estimation accuracy.

Another variable that affected the BBM result is combustion factor, which indicates the ratio of the burned biomass during a fire and is also difficult to estimate because of differences in vegetation characteristics (i.e., plant age, growth cycle, and water content), as well as the unique behavior of each fire. Many researchers have argued that the combustion factor is affected by fire type (surface fire, crown fire, or ground fire), fire phase (flaming or smoldering), and many other factors, such as wind speed, month of occurrence (vegetation has different water content in spring and summer), soil moisture, and even different slope aspects; the different regions ranges of the combustion factor are from $34 \% \sim 69 \%$ with an uncertainty of $50 \%[7,13,56,59,63]$. Uncertainties over the emission factor can also not be ignored and researchers obtained different $E F$ values for boreal forests [13,59].

Burned area is also an important factor that affects $\mathrm{CO}_{2}$ emissions. $\mathrm{CO}_{2}$ emissions from forest fires have a strong correlation with burned area; accurate measurement of burned area has been crucial for $\mathrm{CO}_{2}$ emission estimates [14]. Post-fire burned area could be fairly accurately mapped by airborne and satellite imageries of boreal forests but in this paper, the burned areas were not the post-fire areas. Due to the higher reflectance of burning biomass the burned area may be enlarged in this study. We looked at actively burning forest and freshly burned areas that could correspond with smoke plumes, meaning we could not use any other higher spatial-resolution images aside from those of Aqua MODIS.

Uncertainties in the OCO-2 model may come from the smoke plume area, the modeled $\mathrm{XCO}_{2}$ value of each pixel, as well as the bias of OCO-2 retrieval $\mathrm{XCO}_{2}$ values. In this study, the smoke plumes were identified by the thresholds of MODIS band 8 which were affected by the researcher's knowledge of remote sensing.

O'Dell, et al. [64] argued that the retrieval $\mathrm{XCO}_{2}$ will lead to a small positive bias of about $0.3 \mathrm{ppm}$ when thin cirrus appears. They also defined the clouds as the aerosol optical depth (AOD) greater than 
0.3. In this study we used MODIS product (MYD04, version 061) with a spatial resolution of $3 \mathrm{~km}$ to view the AOD value of wildfire smoke plumes that overlaid with the OCO-2 footprint. We found that all the AOD values of smoke plumes used for the $\mathrm{XCO}_{2}$ model were lower than 0.3 which means that we could ignore this bias. With the increasing AOD of smoke plumes, the modeled $\mathrm{XCO}_{2}$ bias may increase; here we did not consider this error. Thermal Infrared Red (TIR) satellite soundings have low sensitivity below $2-3 \mathrm{~km}$ of altitude, especially in the boundary layer [65], therefore OCO-2 retrieved $\mathrm{XCO}_{2}$ may be underestimated in the smoke plumes boundary layer. We also did not consider this bias in this paper.

\subsection{Advantages and Limitations of the OCO-2 Model}

The OCO-2 model calculates $\mathrm{CO}_{2}$ emissions using the $\triangle \mathrm{XCO}_{2}$ value and smoke plume characteristics that can be obtained using remote-sensing techniques. It has the advantage of remote-sensing technologies repeat data acquisition, such as being more efficient and saving labor costs.

However, there are limitations for the OCO-2 model. Firstly, there may be an error when smoke plumes area is identified. The threshold of the smoke plume area identified was based on artificial visual interpretations, and the accuracy depended on the knowledge and understanding of smoke plume characteristics by researchers. Although MISR data could be used as a reference, some smoke plumes, especially the smoke released from earlier burning, will be dispersed into the atmosphere and could not be captured by the MODIS sensor. To some extent, this could explain why the estimated $\mathrm{CO}_{2}$ emissions using the OCO-2 model are lower than BBM.

Secondly, the most serious limitation of our approach is the lack of data. Given the 16-day recycle time of OCO-2, it is not easy to intersect with the smoke plumes, meaning that smoke from small or short-lived wildfires could not be captured by the OCO-2 satellite. It is time consuming to look for OCO-2 points that intersect MODIS smoke plumes on the same day. In this study, we just attempt to explore a simple and accurate method for using remote sensing data to estimate $\mathrm{CO}_{2}$ emissions from wildfires and in the future, automatic methods for identifying smoke plumes and selecting the intersected OCO-2 points must be developed.

\section{Conclusions}

Every year, thousands of wildfires occur in boreal forests and release a great amount of $\mathrm{CO}_{2}$ into the atmosphere. Wildfires transform forests from carbon sinks into sources. Accurate estimation of GHG, especially $\mathrm{CO}_{2}$ from wildfire in boreal forests, is necessary to understand the role of boreal forests in carbon cycle and global warming. This study explored the feasibility of using OCO-2 and MODIS data to estimate $\mathrm{CO}_{2}$ emissions from wildfires in boreal forests and we were able to draw a few conclusions.

Firstly, $\mathrm{CO}_{2}$ emissions could be calculated using OCO-2 data and Aqua MODIS images because of the close passing time over the same territories. MODIS band 8 and 21 could be used in smoke plume identification and burned area monitoring. Because of the higher reflectance of burning biomass, the burned area identified in this study may be enlarged and lead to higher $\mathrm{CO}_{2}$ emissions from BBM.

Secondly, the widely used biomass burning method, BBM, was used to verify the results of the OCO-2 model and found that the biases were between $25.76 \%$ and $157.11 \%$. The different results between BBM and the OCO-2 model were because of the biases of the smoke plumes area, smoke plume height, burned area, biomass fuel load, and even the different biological communities of the study region with the references.

Thirdly, based on the different $\mathrm{CO}_{2}$ emission results, the advantages and limitations of the OCO-2 model in estimating $\mathrm{CO}_{2}$ emissions from wildfires were analyzed and found that OCO-2 is a useful tool for fire-emission monitoring.

The present study proposed a new approach to estimate $\mathrm{CO}_{2}$ emissions from wildfires using remote-sensing data and extends the application range of GHG satellites. In the future, many works are needed to perfect the OCO-2 model, especially to improve its efficiency and accuracy. 
Author Contributions: Methodology, M.G.; software, L.W.; formal analysis, S.H.; writing—original draft preparation, M.G. and J.L.; writing—review and editing, M.G. and J.L.; funding acquisition, J.L., M.G.

Funding: This research was funded by the National Natural Science Foundation of China (41871103 and 41771179) and the National Key Research and Development Project (2016YFA0602301).

Acknowledgments: We would like to thank the NASA Goddard Earth Science Data and Information Services Center for the use of OCO-2 data in this study. We also would like to thank MISR data of NASA and the MINX v4.0 software of California Institute of Technology.

Conflicts of Interest: The authors declare that there is no conflict of interest.

\section{References}

1. Williams, C.A.; Gu, H.; MacLean, R.; Masek, J.G.; Collatz, G.J. Disturbance and the carbon balance of us forests: A quantitative review of impacts from harvests, fires, insects, and droughts. Glob. Planet. Chang. 2016, 143, 66-80. [CrossRef]

2. Boby, L.A.; Schuur, E.A.G.; Mack, M.C.; Verbyla, D.; Johnstone, J.F. Quantifying fire severity, carbon, and nitrogen emissions in Alaska's boreal forest. Ecol. Appl. 2010, 20, 1633-1647. [CrossRef] [PubMed]

3. Van Marle, M.J.E.; Kloster, S.; Magi, B.I.; Marlon, J.R.; Daniau, A.L.; Field, R.D.; Arneth, A.; Forrest, M.; Hantson, S.; Kehrwald, N.M.; et al. Historic global biomass burning emissions for CMIP6 (BB4CMIP) based on merging satellite observations with proxies and fire models (1750-2015). Geosci. Model Dev. 2017, 10, 3329-3357. [CrossRef]

4. Fisher, D.; Muller, J.P.; Yershov, V.N. Automated stereo retrieval of smoke plume injection heights and retrieval of smoke plume masks from aatsr and their assessment with CALIPSO and MISR. IEEE Trans. Geosci. Remote Sens. 2014, 52, 1249-1258. [CrossRef]

5. Langner, A.; Siegert, F. Spatiotemporal fire occurrence in Borneo over a period of 10 years. Glob. Chang. Biol. 2009, 15, 48-62. [CrossRef]

6. Alexander, H.D.; Mack, M.C. A canopy shift in interior Alaskan boreal forests: Consequences for above- and belowground carbon and nitrogen pools during post-fire succession. Ecosystems 2016, 19, 98-114. [CrossRef]

7. Guo, M.; Li, J.; Xu, J.; Wang, X.; He, H.; Wu, L. CO emissions from the 2010 russian wildfires using gosat data. Environ. Pollut. 2017, 226, 60-68. [CrossRef] [PubMed]

8. Virkkula, A.; Levula, J.; Pohja, T.; Aalto, P.P.; Keronen, P.; Schobesberger, S.; Clements, C.B.; Pirjola, L.; Kieloaho, A.J.; Kulmala, L.; et al. Prescribed burning of logging slash in the boreal forest of Finland: Emissions and effects on meteorological quantities and soil properties. Atmos. Chem. Phys. 2014, 14, 4473-4502. [CrossRef]

9. Seiler, W.; Crutzen, P.J. Estimates of gross and net fluxes of carbon between the biosphere and the atmosphere from biomass burning. Clim. Chang. 1980, 2, 207-247. [CrossRef]

10. Miranda, A.I.; Coutinho, M.; Borrego, C. Forest fire emissions in Portugal: A contribution to global warming? Environ. Pollut. 1994, 83, 121-123. [CrossRef]

11. Wiedinmyer, C.; Neff, J.C. Estimates of $\mathrm{CO}_{2}$ from fires in the United States: Implications for carbon management. Carbon Balance Manag. 2007, 2, 10. [CrossRef] [PubMed]

12. Barbosa, P.; Camia, A.; Kucera, J.; Libertà, G.; Palumbo, I.; San-Miguel-Ayanz, J.; Schmuck, G. Chapter 8 Assessment of Forest Fire Impacts and Emissions in the European Union Based on the European Forest Fire Information System; Elsevier Science \& Technology: Amsterdam, The Netherlands, 2008; pp. 197-208.

13. Van der Werf, G.R.; Randerson, J.T.; Giglio, L.; Collatz, G.J.; Mu, M.; Kasibhatla, P.S.; Morton, D.C.; Defries, R.S.; Jin, Y.; Leeuwen, T.T.V. Global fire emissions and the contribution of deforestation, savanna, forest, agricultural, and peat fires (1997-2009). Atmos. Chem. Phys. 2010, 10, 16153-16230. [CrossRef]

14. Rosa, I.M.D.; Pereira, J.M.C.; Tarantola, S. Atmospheric emissions from vegetation fires in Portugal (1990-2008): Estimates, uncertainty analysis, and sensitivity analysis. Atmos. Chem. Phys. 2011, 11, 2625-2640. [CrossRef]

15. Shi, Y.; Yamaguchi, Y. A high-resolution and multi-year emissions inventory for biomass burning in Southeast Asia during 2001-2010. Atmos. Environ. 2014, 98, 8-16. [CrossRef]

16. Zhou, Y.; Xing, X.; Lang, J.; Chen, D.; Cheng, S.; Wei, L.; Wei, X.; Liu, C. A comprehensive biomass burning emission inventory with high spatial and temporal resolution in China. Atmos. Chem. Phys. 2017, 17, 2839-2864. [CrossRef] 
17. Pereira, G.; Freitas, S.R.; Moraes, E.C.; Ferreira, N.J.; Shimabukuro, Y.E.; Rao, V.B.; Longo, K.M. Estimating trace gas and aerosol emissions over South America: Relationship between fire radiative energy released and aerosol optical depth observations. Atmos. Environ. 2009, 43, 6388-6397. [CrossRef]

18. Liu, M.; Song, Y.; Yao, H.; Kang, Y.; Li, M.; Huang, X.; Hu, M. Estimating emissions from agricultural fires in the North China Plain based on MODIS fire radiative power. Atmos. Environ. 2015, 112, 326-334. [CrossRef]

19. Wooster, M.J.; Freeborn, P.H.; Archibald, S.; Oppenheimer, C.; Roberts, G.J.; Smith, T.E.L.; Govender, N.; Burton, M.; Palumbo, I. Field determination of biomass burning emission ratios and factors via open-path ftir spectroscopy and fire radiative power assessment: Headfire, backfire and residual smouldering combustion in African savannahs. Atmos. Chem. Phys. 2011, 11, 11591-11615. [CrossRef]

20. Kaiser, J.W.; Heil, A.; Andreae, M.O.; Benedetti, A.; Chubarova, N.; Jones, L.; Morcrette, J.J.; Razinger, M.; Schultz, M.G.; Suttie, M. Biomass burning emissions estimated with a global fire assimilation system based on observed fire radiative power. Biogeosci. Discuss. 2012, 9, 527-554. [CrossRef]

21. Konovalov, I.B.; Berezin, E.V.; Ciais, P.; Broquet, G.; Beekmann, M.; Hadjilazaro, J.; Clerbaux, C.; Andreae, M.O.; Kaiser, J.W.; Schulze, E.D. Constraining $\mathrm{CO}_{2}$ emissions from open biomass burning by satellite observations of co-emitted species: A method and its application to wildfires in Siberia. Atmos. Chem. Phys. 2014, 14, 10383-10410. [CrossRef]

22. Konovalov, I.B.; Beekmann, M.; Berezin, E.V.; Formenti, P.; Andreae, M.O. Probing into the aging dynamics of biomass burning aerosol by using satellite measurements of aerosol optical depth and carbon monoxide. Atmos. Chem. Phys. 2016, 17, 4513-4537. [CrossRef]

23. Mu, M.; Randerson, J.T.; Van der Werf, G.R.; Giglio, L.; Kasibhatla, P.; Morton, D.; Collatz, G.J.; Defries, R.S.; Hyer, E.J.; Prins, E.M. Daily and 3-hourly variability in global fire emissions and consequences for atmospheric model predictions of carbon monoxide. J. Geophys. Res. Atmos. 2011, 116, 24303. [CrossRef]

24. Wiedinmyer, C.; Akagi, S.K.; Yokelson, R.J.; Emmons, L.K. The Fire INventory from NCAR (FINN)—A high resolution global model to estimate the emissions from open burning. Geosci. Model Dev. Discuss. 2011, 3, 625-641. [CrossRef]

25. Kaiser, J.W.; Flemming, J.; Schultz, M.G.; Suttie, M.; Wooster, M.J. The MACC Global Fire Assimilation System: First emission products (GFASv0). ECMWF Tech. Memo. 2009, 596, 1-6.

26. Arnett, J.T.; Coops, N.C.; Daniels, L.D.; Falls, R.W. Detecting forest damage after a low-severity fire using remote sensing at multiple scales. Int. J. Appl. Earth Obs. Geoinf. 2015, 35, 239-246. [CrossRef]

27. Heymann, J.; Reuter, M.; Buchwitz, M.; Schneising, O.; Bovensmann, H.; Burrows, J.P.; Massart, S.; Kaiser, J.W.; Crisp, D. $\mathrm{CO}_{2}$ emission of indonesian fires in 2015 estimated from satellite-derived atmospheric $\mathrm{CO}_{2}$ concentrations. Geophys. Res. Lett. 2017, 44, 1537-1544. [CrossRef]

28. Patra, P.K.; Crisp, D.; Kaiser, J.W.; Wunch, D.; Saeki, T.; Ichii, K.; Sekiya, T.; Wennberg, P.O.; Feist, D.G.; Pollard, D.F. The orbiting carbon observatory (OCO-2) tracks 2-3 peta-gram increase in carbon release to the atmosphere during the 2014-2016 EI Nino. Sci. Rep. 2017, 7, 13567. [CrossRef]

29. Connor, B.; Bösch, H.; McDuffie, J.; Taylor, T.; Fu, D.; Frankenberg, C.; O’Dell, C.; Payne, V.H.; Gunson, M.; Pollock, R.; et al. Quantification of uncertainties in OCO-2 measurements of $\mathrm{XCO}_{2}$ : Simulations and linear error analysis. Atmos. Meas. Tech. 2016, 9, 5227-5238. [CrossRef]

30. Wunch, D.; Wennberg, P.O.; Osterman, G.; Fisher, B.; Naylor, B.; Roehl, C.M.; O’Dell, C.; Mandrake, L.; Viatte, C.; Kiel, M. Comparisons of the Orbiting Carbon Observatory-2 (OCO-2) $\mathrm{XCO}_{2}$ measurements with TCCON. Atmos. Meas. Tech. 2017, 10, 1-45. [CrossRef]

31. Crisp, D.; Pollock, H.; Rosenberg, R.; Chapsky, L.; Lee, R.; Oyafuso, F.; Frankenberg, C.; Dell, C.; Bruegge, C.; Doran, G.; et al. The on-orbit performance of the Orbiting Carbon Observatory-2 (OCO-2) instrument and its radiometrically calibrated products. Atmos. Meas. Tech. 2017, 10, 59-81. [CrossRef]

32. Pollock, R.; Haring, R.E.; Holden, J.R.; Johnson, D.L.; Kapitanoff, A.; Mohlman, D.; Phillips, C.; Randall, D.; Rechsteiner, D.; Rivera, J.; et al. The orbiting carbon observatory instrument: Performance of the oco instrument and plans for the OCO-2 instrument. In Proceedings of the SPIE-The International Society for Optical Engineering, Toulouse, France, 13 October 2010.

33. Prasad, P.; Rastogi, S.; Singh, R.P.; Panigrahy, S. Spectral modelling near the $1.6 \mu \mathrm{m}$ window for satellite based estimation of $\mathrm{CO}_{2}$. Spectrochim. Acta A Mol. Biomol. Spectrosc. 2014, 117, 330-339. [CrossRef] [PubMed]

34. Lee, R.A.M.; O’Dell, C.W.; Wunch, D.; Roehl, C.M.; Osterman, G.B.; Blavier, J.F.; Rosenberg, R.; Chapsky, L.; Frankenberg, C.; Hunyadi-Lay, S.L.; et al. Preflight spectral calibration of the Orbiting Carbon Observatory 2. IEEE Trans. Geosci. Remote Sens. 2017, 55, 2499-2508. [CrossRef] 
35. Day, J.O.; O’Dell, C.W.; Pollock, R.; Bruegge, C.J.; Rider, D.; Crisp, D.; Miller, C.E. Preflight spectral calibration of the orbiting carbon observatory. In Proceedings of the International Conference on Next Generation Mobile Applications, Amman, Jordan, 27-29 July 2010; pp. 13-18.

36. Frankenberg, C.; Pollock, R.; Lee, R.A.M.; Rosenberg, R.; Blavier, J.F.; Crisp, D.; O’Dell, C.W.; Osterman, G.B.; Roehl, C.; Wennberg, P.O.; et al. The Orbiting Carbon Observatory (OCO-2): Spectrometer performance evaluation using pre-launch direct sun measurements. Atmos. Meas. Tech. 2015, 8, 301-313. [CrossRef]

37. Meng, J.; Ding, G.; Liu, L.; Zhang, R. A comparison and validation of atmosphere $\mathrm{CO}_{2}$ concentration OCO-2-based observations and tccon-based observations. In Communications in Computer and Information Science; Springer: Singapore, 2016; Volume 645, pp. 356-363.

38. Eldering, A.; O’Dell, C.W.; Wennberg, P.O.; Crisp, D.; Gunson, M.R.; Viatte, C.; Avis, C.; Braverman, A.; Castano, R.; Chang, A.; et al. The Orbiting Carbon Observatory-2: First 18 months of science data products. Atmos. Meas. Tech. 2017, 10, 549-563. [CrossRef]

39. Mandrake, L.; Frankenberg, C.; O’Dell, C.W.; Osterman, G.; Wennberg, P.; Wunch, D. Semi-autonomous sounding selection for OCO-2. Atmos. Meas. Tech. 2013, 6, 2851-2864. [CrossRef]

40. Ross, A. Gosat Measurements of Wildfire Emissions; University of London: London, UK, 2012.

41. Ross, A.N.; Wooster, M.J.; Boesch, H.; Parker, R. First satellite measurements of carbon dioxide and methane emission ratios in wildfire plumes. Geophys. Res. Lett. 2013, 40, 4098-4102. [CrossRef]

42. Chand, T.R.K.; Badarinath, K.V.S.; Murthy, M.S.R.; Rajshekhar, G.; Elvidge, C.D.; Tuttle, B.T. Active forest fire monitoring in Uttaranchal State, India using multi-temporal DMSP-OLS and MODIS data. Int. J. Remote Sens. 2007, 28, 2123-2132. [CrossRef]

43. Guo, M.; Li, J.; Sheng, C.; Xu, J.; Li, W. A review of wetland remote sensing. Sensors 2017, 17, 777. [CrossRef]

44. Roy, D.; Descloitres, J.; Alleaume, S. The MODIS fire products. Remote Sens. Environ. 2002, 83, $244-262$.

45. Cheng, D.; Rogan, J.; Schneider, L.; Cochrane, M. Evaluating MODIS active fire products in subtropical yucatán forest. Remote Sens. Lett. 2013, 4, 455-464. [CrossRef]

46. Chen, D.; Pereira, J.M.C.; Masiero, A.; Pirotti, F. Mapping fire regimes in China using MODIS active fire and burned area data. Appl. Geogr. 2017, 85, 14-26. [CrossRef]

47. Ganci, G.; Negro, C.D.; Fortuna, L.; Vicari, A. A tool for multi-platform remote sensing processing. Commun. Simai Congr. 2009, 3, 281.

48. Wan, Z.; Ng, D.; Dozier, J. Spectral emissivity measurements of land-surface materials and related radiative transfer simulations. Adv. Space Res. 1994, 14, 91-94. [CrossRef]

49. Mazzoni, D.; Logan, J.A.; Diner, D.; Kahn, R.; Tong, L.; Li, Q. A data-mining approach to associating MISR smoke plume heights with MODIS fire measurements. Remote Sens. Environ. 2007, 107, 138-148. [CrossRef]

50. Kahn, R.A.; Moroney, C.M.; Gaitley, B.J.; Nelson, D.L.; Garay, M.J.; Mims, S.R. MISR stereo heights of grassland fire smoke plumes in Australia. IEEE Trans. Geosci. Remote Sens. 2009, 48, 25-35.

51. Gonzalez, L.; Val Martin, M.; Kahn, R. Biomass burning smoke heights over the Amazon observed from space. Atmos. Chem. Phys. 2019, 19, 1685-16702. [CrossRef]

52. Nelson, D.L.; Garay, M.J.; Kahn, R.A.; Dunst, B.A. Stereoscopic height and wind retrievals for aerosol plumes with the MISR INteractive eXplorer (MINX). Remote Sens. 2013, 5, 4593-4628. [CrossRef]

53. Sofiev, M.; Ermakova, T.; Vankevich, R. Evaluation of the smoke-injection height from wild-land fires using remote-sensing data. Atmos. Chem. Phys. 2012, 11, 27937-27966. [CrossRef]

54. Kahn, R.A.; Li, W.H.; Moroney, C.; Diner, D.J.; Martonchik, J.V.; Fishbein, E. Aerosol source plume physical characteristics from space-based multiangle imaging. J. Geophys. Res. Atmos. 2007, 112, 1-20.

55. Goto, Y.; Suzuki, S. Estimates of carbon emissions from forest fires in Japan, 1979-2008. Int. J. Wildland Fire 2013, 22, 721-729. [CrossRef]

56. Chang, D.; Song, Y. Estimates of biomass burning emissions in tropical Asia based on satellite-derived data. Atmos. Chem. Phys. 2010, 10, 2335-2351. [CrossRef]

57. Shi, Y.; Matsunaga, T.; Yamaguchi, Y. High-resolution mapping of biomass burning emissions in three tropical regions. Environ. Sci. Technol. 2015, 49, 10806-10814. [CrossRef] [PubMed]

58. Shi, Y.; Sasai, T.; Yamaguchi, Y. Spatio-temporal evaluation of carbon emissions from biomass burning in Southeast Asia during the period 2001-2010. Ecol. Model. 2014, 272, 98-115. [CrossRef]

59. Akagi, S.K.; Yokelson, R.J.; Wiedinmyer, C.; Alvarado, M.J.; Reid, J.S.; Karl, T.; Crounse, J.D.; Wennberg, P.O. Emission factors for open and domestic biomass burning for use in atmospheric models. Atmos. Chem. Phys. 2011, 11, 4039-4072. [CrossRef] 
60. Vadrevu, K.; Ellicott, E.; Giglio, L.; Badarinath, K.V.S.; Vermote, E.; Justice, C.; Lau, W. Vegetation fires in the himalayan region—aerosol load, black carbon emissions and smoke plume heights. Atmos. Environ. 2012, 47, 241-251. [CrossRef]

61. Wu, Y.; Cordero, L.; Gross, B.; Moshary, F.; Ahmed, S. Smoke plume optical properties and transport observed by a multi-wavelength lidar, sunphotometer and satellite. Atmos. Environ. 2012, 63, 32-42. [CrossRef]

62. Saatchi, S.S.; Harris, N.L.; Brown, S.; Lefsky, M.; Mitchard, E.T.; Salas, W.; Zutta, B.R.; Buermann, W.; Lewis, S.L.; Hagen, S. Benchmark map of forest carbon stocks in tropical regions across three continents. Proc. Natl. Acad. Sci. USA 2011, 108, 9899. [CrossRef] [PubMed]

63. Kauffman, J.B.; Steele, M.D.; Cummings, D.L.; Jaramillo, V.J. Biomass dynamics associated with deforestation, fire, and conversion to cattle pasture in a Mexican tropical dry forest. For. Ecol. Manag. 2003, 176, 1-12. [CrossRef]

64. O'Dell, C.W.; Connor, B.; Bösch, H.; O'Brien, D. The ACOS $\mathrm{CO}_{2}$ retrieval algorithm-Part 1: Description and validation against synthetic observations. Atmos. Meas. Tech. 2011, 4, 99-121.

65. Yurganov, L.N.; Rakitin, V.; Dzhola, A.; August, T.; Fokeeva, E.; George, M.; Gorchakov, G.; Grechko, E.; Hannon, S.; Karpov, A. Satellite- and ground-based CO total column observations over 2010 Russian fires: Accuracy of top-down estimates based on thermal IR satellite data. Atmos. Chem. Phys. Discuss. 2011, 11, 7925-7942. [CrossRef]

(C) 2019 by the authors. Licensee MDPI, Basel, Switzerland. This article is an open access article distributed under the terms and conditions of the Creative Commons Attribution (CC BY) license (http://creativecommons.org/licenses/by/4.0/). 